\title{
The Effect of country risk on foreign direct investment: Evidence from Egypt
}

\author{
Rania Salem \\ The British University in Egypt
}

\author{
Reem Younis \\ The British University in Egypt
}

\begin{abstract}
This paper examines the effect of country risk on Foreign Direct Investment (FDI) in Egypt during the years 2005 - 2015. We employ multiple regression analysis, to test the relationship among the selected variables that drive foreign direct investment flows to Egypt. FDI has always been an interesting topic for research; nevertheless, to the authors' knowledge, the impact of country risk on FDI has not been examined before in Egypt. Since FDI is a notable source of foreign currency income to the Egyptian economy, it becomes inevitable to study the variables that affect the flow of FDI in relevance to the economic outlook in general and country risk in specific. The effect of country risk on FDI could significantly affect economic measurements such as economic growth and required rate of return. Our results show that economic risk measurements have the most significant impact on foreign direct investments inflows to Egypt, while financial risk measurements have no significance. Moreover, political risk is associated with foreign direct investment.

JEL classification: F21; F23; F3; F65; G32
\end{abstract}

Keywords: Foreign direct investment; Country risk; Economic risk; Financial risk; Political risk; Egypt 
تبحث هذه الدراسة مدى تأثير مخاطر الدولة على الاستثمار الأجنبي المباشر في

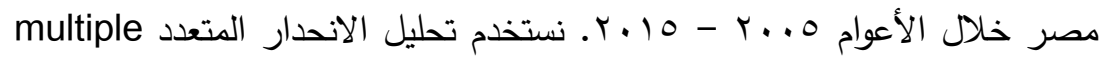
regression analysis

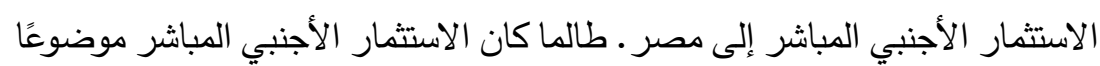

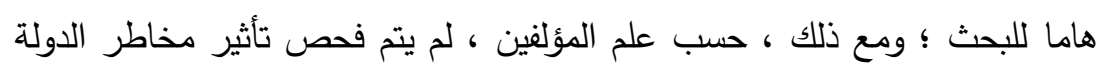
على الاستثمار الأجنبي المباشر في مصر من قبل. نظرًا لأن الاستثمار الأجنبي

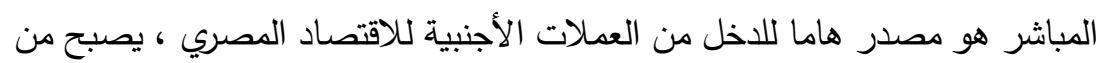

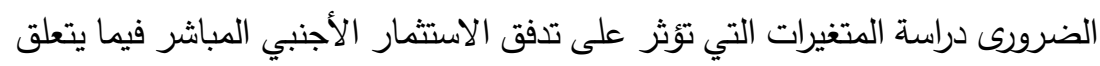

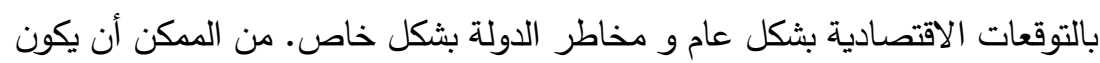

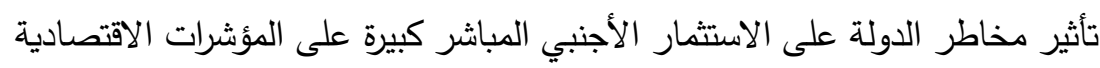

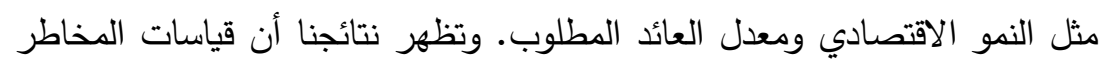

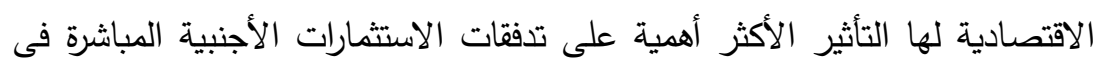

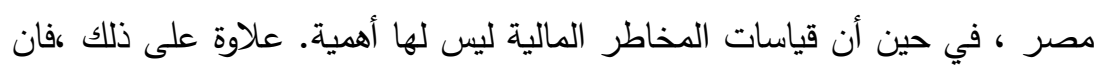

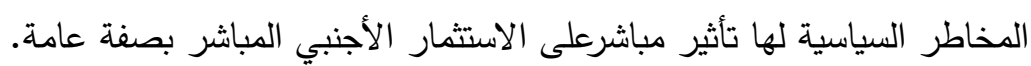

الكلمات المفتاحية: الاستثمار الأجنبي المباشر؛ مخاطر الدولة ؛ المخاطر

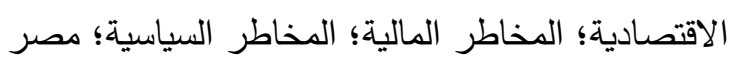




\section{INTRODUCTION}

Economic growth is a goal for every country. One of the means of economic growth is foreign direct investments (FDI) . The amount of FDI inflows as percentage of gross domestic product (GDP) has been deteriorating in Egypt since 2006. It reached its peak in 2009 and started to decrease afterwards. In addition, Egypt witnessed a decline in FDI inflows 2011 amounting to $20 \%$. In general, FDI should have a positive impact on the economy, as it can positively affect technology and employment. However, there is no consensus in the literature on the effect of FDI on economic growth. While some researchers confirm a positive direct relationship between FDI and economic growth like Belloumi (2014), other researchers, such as Law (2010) argue that a positive relationship might not hold. Rehman (2016) confirms that the flow of FDI into the host country, has its positive spillovers such as, human capital, progressive technology, improvement in managerial skills, and international relations. On the other hand, Law (2010) states that there is a benchmark that must be crossed in order to recognize the positive relationship, otherwise the relationship is non-existent. One of the crucial determinants of FDI is country risk. Country risk as a concept includes many variables but the important note is that all potential investors, no exceptions, look for country risk in order to assess and forecast their investment into a specific country. In addition, one of the reasons that foreign capital flows are focused into developing markets is that most economies are marketoriented. This indicates that economies are free, where there are no extreme restrictions, which makes developing countries more attractive for foreign investors than developed countries.

The relationship between country risk and FDI has been studied multiple times by different researchers such as, Al-Khouri (2015), Hogan, Lipton and Olson (2015), Rogmans and Ebbers (2013), and Steiner (2010). However, each research uses different dimensions in assessing the relationship. For example, Al-Khouri (2015) identifies country risk, size of the economy, trade 
openness among other variables as factors that affect FDI. Others like Elshamy (2015) identifies market size, and natural resources as measurements of assessing FDI. Moreover, to the best of the authors knowledge almost no studies had been conducted on Egypt to determine the most important variable of country risk while assessing foreign investments. However, researchers like Naguib and Xu (2016), Zghidi, Sghaier and Abida (2016) and Elshamy (2015) studied FDI in general, but not specifically on the relationship between country risk and FDI in Egypt. Conversely, since country risk affects each investment across all industries, it becomes important to address the impact of country risk, based on the different characteristics of every country, on investments in general and FDI specifically. Moreover, since Egypt has not been investigated throughout the literature, attention is due in this area to count for the impact of country risk on FDI in Egypt .

In this research, country risk is assessed in respect to economic, financial and political risks in order to determine their effect on FDI flows. The effect of country risk on FDI has a significant impact on economic measurements such as economic growth and required rate of return and hence the importance of this study.

In the case of Egypt, FDI is needed as it helps in improving economic development and improves the external position of the country among other benefits. Also, country risk ratings in Egypt have been changing constantly in the past years. Starting 2011, Egypt had a negative outlook and a rating of low Bs and Cs according to Fitch, Moody's and S\&P rating agencies. Starting mid-2013, Egypt started to have a more stable outlook of high Bs ratings . Consequently, this research is very important as it addresses the variable that Egypt needs the most; FDI, and addresses the variable which has a significant impact on FDI as it is changing over the years; country risk. Therefore, this research aims to study the relationship between FDI and country risk throughout 10 years; from 2005-2015 using regression analysis. The objective of this study is two-fold. First, it investigates the nature of FDI and country risk in Egypt. Second, it provides an 
empirical analysis by examining the relationship between FDI and country risk in Egypt and determines whether FDI inflows can promote economic growth. Country risk is considered as a measure of macroeconomic environment, measured by economic, financial, and political risks.

The research contributes to the existing literature on the relationship between FDI inflows and country risk in nondeveloped countries. Although a few studies have investigated this relationship in the MENA region (Al-Khouri, 2015; Rogmans \& Ebbers, 2013; Vijayakumar, Rasheed \& Tondkar, 2009; Chakrabarti, 2001; Nordal, 2001), this is the first attempt to examine the effect of FDI on macroeconomic environment in Egypt.

The rest of the paper is divided as follows: section two reviews the relevant theoretical literature and develops the hypotheses for FDI and country risk. Section three presents the methodology, while section four provides a discussion of the results, and finally section five concludes the study.

\section{FOREIGN DIRECT INVESTMENT}

Foreign Direct Investment (FDI) had been known for its significant and positive impact on the growth of the host country, consequently, developing countries try to attract FDI by different means (Al-Khouri, 2015). MENA region, as part of the many emerging countries, have been taking initiatives toward the encouragement of FDI inflows, through macroeconomic factors, institutional factors, and tax exemption policies (Tung \& Cho, 2001; Rogmans \& Ebbers, 2013).

There is a belief that the inflows of FDI is of huge impact on a country's economic growth. Researchers like Rahmen (2016), Belloumi (2014), Law (2010), Meyer \& Sinani (2009) and Lipsey (2001) studied the relationship between FDI and economic growth. The absorption of large production knowledge, expertise and innovation, and importation plays a significant part in upgrading the skills of workers in a country, and also in upgrading 
the technological mentality of the population. So, one of the reasons why FDI impact economic growth is because of the accumulation of physical and technological wealth flowing into the country. Likewise, the supply of fund is impacted by the FDI inflows as it plays a crucial role in the financials of a country. On the other hand, Law (2010) states that if the financial development after the FDI flows exceeded a specific verge, there will be an impact on economic growth. Otherwise, FDI benefits are unreal. Lastly, Meyer and Sinani (2009), along with Lipsey (2001), states that one of the important spillovers of FDI is the transfer of technology and expertise in management.

Through the numerous researches studied by different researchers, each research had its own individual determinants of FDI flows from a specific point of view which resulted in having too many determinants for the same dependent variable -FDI(Rehman, 2016).

Most of the literature focusing on FDI identifies some factors that affect the attraction ability of host countries. According to Chakrabarti (2001) and Kamaly (2002), the most significant attraction forces are market openness, infrastructure quality, political stability, the extent of economic distortion and the institutional environment of the host country. Also, Onyeiwu (2004) identifies openness and corruption as the most significant factors of FDI according to his study which compares FDI flows to MENA region and other developing countries from 1975 till 1999. In addition, Onyeiwu (2004) states that economic growth indicators, such as GDP growth, have a significant positive relationship associated with FDI. Onyeiwu (2008) used a sample of 61 developing countries, including MENA region. It was found that the most crucial determinants of FDI are openness of the economy, GDP per capita and political risk. Steiner (2010) carried Onyeiwu's research further focusing mainly on MENA countries, especially Egypt. He focused on the relationship between FDI flows and political instability, but his study was unable to determine a specific relationship between both variables. Furthermore, Rogmans \& Ebbers (2013) states that the 
determinants of FDI in the MENA region are market size, trade openness, political risk and business operating conditions. Where, for example, market size is concerned with spending power of consumers which is associated with high GDP which influences the wage rates, making a country less attractive. Additionally, a study conducted by Kok and Ersoy (2009) concludes that FDI flows is positively affected by gross capital formation, trade, and GDP per capita growth while it is negatively affected by total foreign debt as ratio of GDP and inflation. Mall (2013) agrees with Kok and Ersoy. Paudel (2016), on the other hand, contradicts Kok and Ersoy's (2009) and Mall's (2013) view. Paudel (2016) states that factors negatively influencing FDI are GDP growth, labor force, education, and trade reforms. On the other hand, factors positively influencing FDI are inflation, GDP growth per capita and increased governance. In addition, a study conducted by Hunjra et al. (2013) suggests that factors such as GDP growth and interest rate have important impact on FDI flows while inflation and exchange rate does not have any impact. Which conforms to Kok and Ersoy (2009) but contradicts with Paudel (2016). Moreover, a research conducted by Rauf et al. (2016) examines the effect of political outlook and terrorism and their study determines that GDP, political stability and trade openness positively influence FDI flows and also determines that terrorism has a substantial influence on FDI flows to a host country.

Furthermore, Researchers like Hogan, Lipton \& Olson (2015), Al-Khouri (2015), and Click (2005) agrees that the main determinant of FDI is country risk. However, their analysis of country risk was different. Hogan, Lipton \& Olson (2015) identifies country risk as economic, financial, and political risk. Likewise, Al-Khouri concluded the same factors. Click (2005), on the other hand, identifies country risk as political and financial risks only. In addition, Click (2005) states that the political risk is primarily conceptual and subjective.

Various researches have been conducted in order to explore the relationship between FDI flows and its numerous determinants. It was found that Country Risk has the most effect on FDI flows in 
the MENA region according to Al-Khouri (2015), Rogmans \& Ebbers (2013), Vijayakumar, Rasheed \& Tondkar (2009), Chakrabarti (2001), Nordal (2001), among others.

In reference to the above literature, the indicators to be discussed are the most influential factors affecting capital flows into the MENA region. Bearing in mind that there are a lot of other factors affecting FDI flows but it differs among countries, as discussed before.

Country risk refers to every possible element of risk associated with entering another country. Country risk includes economic, social, financial, and political risks. It is defined as the inability or unwillingness to satisfy its financial obligations, and nowadays, this is the major concern for every company trying to enter a foreign country (Cosset \& Roy, 1991). Herring (1983) defines country risk as a "broad range of actions taken by (or allowed by) the sovereign power that have unfavourable consequences for foreign investors." Country risk as a concept had been studied many times, so its variables or factors vary among different researches. Al-Khouri (2015) identifies economic, financial and political risks as the only factors affecting country risk. Vijayakumar, Rasheed and Tondkar (2009) identifies political risk, economic performance (present and upcoming), credit ratings and many more other indicators as determinants of country risk, but only focused on political risk as the main indicator. Lastly, a Country Risk Assessment "CRA" study indicates that there is no comprehensive theory for country risk and identifies economic factors, exchange rate, location or neighbourhood, sovereign, and political risks as indicators of country risk.

Similarly, the measurement methods used by researches to quantify country risk vary from one study to another. Some studies developed the analytical hierarchy process as an assessment of country risk and included economic, political, geographic, social and institutional dimensions as characteristics in assessing country risk. Other studies used country risk measures from Euromoney magazine, which publishes country 
risk and country rating every year in March and September. Based on this assessment, country risk was measured by political risk, economic performance, debt indicators and many other measurement categories. Al-Khouri (2015) used generalized methods of moments (GMM) regression and got information on political, financial and economic risks from International Country Risk Rating (ICRG) which is provided by Political Risk Analysis (PRS) Group. She used several measures other than economic, financial and political risks, such as trade openness and return on investment. Similarly, Haider (2014) collected data about political risk from ICRG and used multiple linear regression in the analysis. The ICRG was also used by Nordal (2001).

There is no consensus in the literature regarding the variables that identify country risk. However, the most common dimensions are, economic, financial, and political risks, according to studies conducted by researchers such as Al-Khouri (2015), Hogan, Lipton \& Olson (2015), Liu, Hammoudeh \& Thompson (2013) and Meldrum (2000). Hence, this research follows the same classification of country risk.

\section{COUNTRY RISK 3.1 ECONOMIC RISK}

Market, competition and technological changes are the factors associated with economic risk that reduce the business's intention to succeed which is also reflected on the profits estimate (AlKhouri, 2015). Wyk and Lal. (2010) state that country productivity is associated with macroeconomic environment of that country. Thus, with a higher economic risk, comes a very high required rate of return, and both variables increase together; as economic risk increases, required rate of return also increase. And in reference to Iqbal (2001), there has always been a struggle in the MENA region countries to sustain macroeconomic stability.

Al-Khouri (2015) states the components affecting economic risk are GDP per capita of population, real annual GDP growth, 
annual inflation rate, budget balance as a percentage of GDP, and current account balance as a percentage of GDP. Meldrum (2000) states that variations in economic arrangement or growth rate results in substantial changes in estimated return on investment (ROI). He also states that economic risk arises from harmful and negative changes arising in the fundamental economic fiscal, monetary policies. Moreover, macroeconomic indicators might influence the economic risk of a host country such as inflation volatility and exchange rate stability. Internal and external shockwaves taken by a country can be reflected by the exchange rates and inflation rates. Because both variables simply reflect how stable a country is in terms of economic and monetary policies. Rogmans (2013) specifies that the already existing FDI, attract more FDI which means that when a country has many FDI existing in its nation, it attracts others to become potential investors. He also proves in his research that FDI gets affected significantly and negatively by economic risk.

Researchers who studied economic risk measured different combinations of factors such as, GDP per capita, real GDP growth, annual inflation rate, and current account as \% of GDP. As concluded from the literature, this research expects a negative association between economic risk and FDI flows and uses the above stated factors as a proxy to capture economic risk. Accordingly, we can hypothesize that economic risk has a negative influence on FDI flows to Egypt.

\subsection{FINANCIAL RISK}

Financial risk is one of the major concerns that any international company intending to invest in another country has. Because FDI tends to be harder to liquidate so companies are very sceptical when it comes to financial risk. However, financial risk as a measurement of country risk has not been studied a lot in the recent years so the variable lacks up-to-date debating literature perspectives. Financial risk is defined as the country's inability to repay foreign obligations and liabilities. Countries with too much 
foreign debt tend to be less attractive to potential investors because as the amount of foreign debt increases, the probability of defaulting and not being able to meet obligations increase, and thus, higher financial risk. And as the financial risk increases, that country is more likely to face financial crisis (Al-Khouri, 2015). As Choi and Tsai (2015) suggests, between the period 1992 and 1998, investments taking place by American companies were mergers and acquisitions (M\&As), not pure direct investments, or in other words greenfield investments. When investors are choosing between either M\&As and FDI, their decisions depend on how the company will be valued in the host country's market. If there is a perfect case where the financial and real markets are in equilibrium state and are efficient, then there is no difference between either investing in another country or at home, or either in the form of M\&As or greenfield investment. In addition, as Aliber (1970) suggests, when investing in a country, investors are concerned about the exchange rates. He suggests that with higher foreign exchange rates stability, comes lower country risk, and thus, cost of capital will be lower for the multinational company. A depreciation in the host country's currency is associated with a reduction in value of the company's assets, in that case, some companies may need to borrow money from external entities. However, this is hard to be done because of the monitoring costs, additional costs, and foreign currency fluctuations.

Furthermore, one of the main factors affecting the increase or decrease of financial risk is the budget deficit, when a country is facing high amounts of current account deficit or facing high amounts of budget deficit and the situation staying that way for many years, that country will likely have no choice but to borrow in order to finance their deficit. This flow of foreign debts will result in an increase in financial risk (Al-Khouri, 2015).

Moreover, the instability in exchange rates affect the host country's FDI inflows as this problem will raise the uncertainty of home country regarding upcoming events and actions. Also, as inflation rate rises, investments coming from abroad may get affected through the future returns as the value of money changes 
from time to time according to inflation rate and exchange rate (Al-Khouri, 2015; Dutta \& Roy, 2011).

Researchers who studied financial risk measured different combinations of factors such as, foreign debt as percentage of GDP, foreign debt as percentage of exports of goods and services, current account as percentage of exports of goods and services and exchange rate stability.

This research expects a negative association between financial risk and FDI flows and this study will use the above-mentioned factors proxy for financial risk. Accordingly, we can hypothesize that financial risk has a negative influence on FDI flows to Egypt.

\subsection{POLITICAL RISK}

Political risk is pre determinant for country risk that very few had shed lights on. Click (2005) stated that political risk is mainly conceptual and subjective according to the experts. On the other hand, Al-Khouri (2015) defined political risk as the circumstances outside the host country's control that happens and increase the likelihood of inability or unwillingness to offer or guarantee a promising business investment atmosphere. This may happen because of country's policies and/or events. Also, the term political risk had been defined as "the possibility that political decisions, events, or conditions in a country, including those that might be referred to as social, will affect the business environment such that investors will lose money or have a reduces profit margin".

Moreover, the possibility of revolutions and political restrictions are the two extremes of political instability. Foreign countries intending to invest in a country with high political risk usually requires a higher return in order to compensate for this risk (Bulter \& Joaquin, 1998). On the other hand, a study of Chinese FDI found that there is a positive relationship between FDI flows and political risk. This study suggests that the difference in perceptions and risk preferences are the things that determine whether to invest in a specific country or not. 
As cited in Al-Khouri (2015), indicators used in assessing political risk includes government stability, socio-economic pressures, investment profile, internal conflict, external conflict, corruption, military influence in politics, religious tensions, law and order, ethnic tension, democratic accountability, and quality of bureaucracy. Also, Busse and Hefeker (2005) agrees with AlKhouri (2015) in terms of political risk indicators. Then, Massoud and Rainborn (2003) divided political risk into two categories: politics and policies. In politics, their criteria were government stability, likelihood of terrorism, and government's control of information. In policies, their criteria were financial regulations, laws of labor, and environmental policies overall.

On the other hand, ODI (1997) identifies political risk in terms of level of crime, riots, disputes of labor and corruption, also he states that these are the factors that can significantly decrease FDI into the country.

Onyeiwu (2008) in his study on MENA region found that political risk is negatively associated with FDI in the region, which means that as the political risk increases, the FDI flows decrease. However, when Steiner (2010) carried out the research in the Middle East, he could not determine a clear correlation between political instability (risk) and FDI flows. Also, in a study by Harms and Ursprung (2002), it was found that the more the political freedom, the more FDI flows into the country. On the other hand, Al-Khouri (2015) indicates that these three factors affected political risk which are; law and order, ethnic tension, and internal conflicts, these factors affect FDI flows negatively because as discussed in the above literature, as political risk increase, FDI flows decrease substantially.

Researchers who studied political risk measured different combinations of factors such as, corruption, payment delay, consumer confidence, unemployment, terrorism, and war.

This research expects a negative association between political risk and FDI flows and use political risk ratings provided by Bloomberg as a proxy for political risk. Accordingly, we can hypothesize that political risk has a negative influence on FDI flows to Egypt. 


\section{FOREIGN DIRECT INVESTMENT AND COUNTRY RISK IN EGYPT}

As discussed in the literature, Egypt has received no attention in academic context in respect to the relationship between FDI and country risk. Therefore, the researcher had to look into reports published by banks, rating agencies and authorities instead of academic resources. In recent economic researches about Egypt, conducted by the Central Bank of Egypt (CBE), the financial and capital account recorded an increase in net inflows from US\$ 1.6 billion to US\$ 7.1 billion as a result of an increase in net inflows of FDI in Egypt, and net outflows of portfolio investment in Egypt.

An increase in the inflows of oil sector investments from US\$ 154.1 million to US\$ 495.5 million and also, an increase in the greenfield investments' inflows from US\$ 1.1 billion to US\$ 1.4 billion resulted in the increase of net inflows of FDI in Egypt from around US\$ 1.4 billion to some US\$ 1.9 billion. Moreover, looking into the breakdown of FDI inflows, it is found that the oil sector has the biggest share of the total inflows which is 52.9 percent. Followed by a group of other sectors, FDI flew to services sectors with 10.9 percent scattered as follows: inflows to real estate sector contributes with 0.7 percent, financial sector contributes with 4.3 percent and other services sectors contribute with 5.9 percent as shown in the figure 1 below.

Furthermore, inflows to manufacturing sector contribute with 1.5 percent, construction sector contributes with 1 percent and the rest of the pie was acquired by undistributed sectors.

Additionally, the net outflows of portfolio investments recorded US\$ 840.9 million compared to US\$ 1.4 billion. US\$ 1.4 billion was mainly resulting from the settlement of bonds worth US\$1.0 billion.

Country risk and country rating in Egypt were affected severely by all the economic, financial and political situations happening in the country, starting from 2011 revolution, until the Egyptian Pound floatation. Credit rating agencies such as Moody's, 
Standard and Poor's and Fitch published their ratings and all were by Trading Economies to have accessible and easier comparison. From the year 2005 till 2009, Egypt had somehow stable economic outlook according to most of the mentioned agencies. Starting 2010 and mid late 2013, Egypt took a severe downfall in its outlook, most agencies had a negative rating for the country. At that time interval, the revolution had happened, and was still going, presidential elections took place in addition to other political events. On the other hand, starting 2014 and until late 2016, Egypt improved its outlook and had positive stable ratings.

\section{RESEARCH METHODOLOGY \\ 5.1 RESEARCH AIM}

This research investigates the impact of country risk, which includes economic, financial, and political risks, as the independent variables, on foreign direct investment, as the dependent variable, in Egypt. Accordingly, we conclude the following research hypotheses:

Economic risk has a negative effect on foreign direct investment inflows to Egypt.

Economic risk has no effect on foreign direct investment inflows to Egypt.

Financial risk has a negative effect on foreign direct investment inflows to Egypt.

Financial risk has no effect on foreign direct investment inflows to Egypt.

Political risk has a negative effect on foreign direct investment inflows to Egypt.

Political risk has no effect on foreign direct investment inflows to Egypt. 


\subsection{SAMPLING AND VARIABLE SELECTION}

Time series analysis is conducted to test the relationship between country risk and FDI flows to Egypt during the period 2005-2015. This research mainly tackles two variables; foreign direct investment and country risk. Country risk is divided into three sub-variables, namely, economic, financial, and political risks. Through which, the foreign direct investment will act as the dependent variable and the three sub-variables of country risk will act as the independent variables. Hence, any changes in patterns of foreign direct investment are more likely to be caused by economic, financial, or political risks, while holding all other variables constant.

FDI as a variable had been studied numerous times in Egypt, MENA region and globally. However, studies conducted in Egypt did not tackle the relationship between FDI and country risk and since Egypt is in need of FDI, this research is vital. In light of the previously discussed literature, we focus on country risk and its three main variables. Table 1 summarizes the variable selection, the sources of data, and the expected effect of each variable on FDI.

Economic risk: Economic risk is measured with GDP per capita and real GDP growth, annual inflation rate, and current account as a percentage of GDP.

Financial risk: Financial risk is measured with foreign debt as a percentage of export of goods and services, current account as a percentage of exports of goods and services and exchange rate stability in terms of local currency units per US\$.

Political risk: Political risk is measured by political risk ratings. 
The effect of country risk Rania Salem \& Reem Younis Accepted date 18/2/2020

Table 1: Summary of Variables

\begin{tabular}{|c|c|c|c|}
\hline Variables & Description & Source of Data & $\begin{array}{l}\text { Expected } \\
\text { Effect }\end{array}$ \\
\hline \multicolumn{4}{|l|}{$\begin{array}{l}\text { Dependent } \\
\text { Variable }\end{array}$} \\
\hline FDI\%GDP & $\begin{array}{lr}\text { Foreign } & \text { direct } \\
\text { investment } & \text { as } \\
\text { percentage of GDP }\end{array}$ & $\begin{array}{l}\text { World Bank's } \\
\text { World Development } \\
\text { Indicators. }\end{array}$ & \\
\hline \multicolumn{4}{|l|}{$\begin{array}{l}\text { Independent } \\
\text { Variable } \\
\end{array}$} \\
\hline \multicolumn{4}{|l|}{ Economic Risk } \\
\hline GDP/CAPITA & GDP per capita & $\begin{array}{l}\text { World Bank's } \\
\text { World Development } \\
\text { Indicators. }\end{array}$ & + \\
\hline $\begin{array}{l}\text { GDP } \\
\text { GROWTH }\end{array}$ & Real GDP growth & $\begin{array}{l}\text { World Bank's } \\
\text { World Development } \\
\text { Indicators. }\end{array}$ & + \\
\hline INFLATION & Inflation rate & $\begin{array}{l}\text { World Bank's } \\
\text { World Development } \\
\text { Indicators. }\end{array}$ & - \\
\hline $\begin{array}{l}\text { CURR ACC } \\
\% \text { GDP }\end{array}$ & $\begin{array}{l}\text { Current account as } \\
\text { percentage of GDP }\end{array}$ & $\begin{array}{l}\text { World Bank's } \\
\text { World Development } \\
\text { Indicators. }\end{array}$ & $+1-$ \\
\hline \multicolumn{4}{|l|}{ Financial Risk } \\
\hline $\begin{array}{l}\text { FOREIGN } \\
\text { DEBT }\end{array}$ & $\begin{array}{l}\text { Foreign Debt as \% } \\
\text { of Export of Goods } \\
\text { and Services }\end{array}$ & $\begin{array}{l}\text { World Bank's } \\
\text { World Development } \\
\text { Indicators. }\end{array}$ & - \\
\hline $\begin{array}{ll}\text { CURR } & \text { ACC } \\
\% \text { EXP } & \end{array}$ & $\begin{array}{lr}\text { Current } & \text { Account } \\
\text { as \% of Exports of } \\
\text { Goods } \\
\text { Services }\end{array}$ & $\begin{array}{l}\text { World Bank's } \\
\text { World Development } \\
\text { Indicators. }\end{array}$ & + \\
\hline $\begin{array}{l}\text { FX } \\
\text { STABILITY }\end{array}$ & $\begin{array}{l}\text { Exchange Rate } \\
\text { Stability (LCU per } \\
\text { US\$) }\end{array}$ & $\begin{array}{l}\text { World Bank's } \\
\text { World Development } \\
\text { Indicators. }\end{array}$ & + \\
\hline \multicolumn{4}{|l|}{ Political Risk } \\
\hline Rating & $\begin{array}{ll}\text { Composite } & \text { Risk } \\
\text { Scores } & \\
\end{array}$ & $\begin{array}{l}\text { Bloomberg Country } \\
\text { Risk Political Scores }\end{array}$ & $+/-$ \\
\hline
\end{tabular}


This research examines Egypt's characteristics in terms of economic, financial and political risks. Since this research focuses on Egypt only, data is collected from Central Bank of Egypt, World Bank's World Development Indicators, and Bloomberg. Information on country risk is from the ICRG provided by the PRS Group. However, ICRG's political risk variables were not available so political risk ratings provided by Bloomberg Country Risk Political Scores for Egypt were used instead. Foreign direct investment inflows, economic risk and financial risk variables data were collected from World Bank's World Development Indicators.

After running a correlation test between the independent and dependent variables, the correlation matrix showed very high correlation between variables as shown in table 2 .

Therefore, in order to test for the multicollinearity, a reliability test is conducted for measurements of economic, political and financial risks individually. The results showed that inflation rate and GDP per capita measures should be eliminated from economic risk to end up having only real GDP growth and current account as percentage of GDP as measurements of economic risk with Cronbach's alpha of 0.66, which is accepted based on Churchill (1979).

Another reliability test was conducted for financial risk. The results showed that the current account as percentage of exports of goods and services should be eliminated to end up having only foreign debt as percentage of goods and services and foreign exchange stability as measurements of financial risk with Cronbach's alpha of 0.647 . No reliability test for political risk was conducted as it is only one measurement which is the political risk rating. 
The effect of country risk $\quad$ Rania Salem \& Reem Younis Accepted date 18/2/2020

Table 2 Correlations Matrix

$\begin{array}{lllllllll}\text { FDI } & \text { POL } & \text { GDP/ } & \text { GD } & \text { INF } & \text { CU } & \text { FO } & \text { CU } & \text { FX } \\ \% \text { G } & \text { ITIC } & \text { CAPI } & \text { P } & \text { LAT } & \text { RR } & \text { REI } & \text { RR } & \text { STA } \\ \text { DP } & \text { AL } & \text { TA } & \text { GR } & \text { ION } & \text { AC } & \text { GN } & \text { AC } & \text { BILI } \\ & \text { RIS } & & \text { OW } & & \text { C } & \text { DE } & \text { C } & \text { TY }\end{array}$

\begin{tabular}{|c|c|c|c|c|c|c|c|c|}
\hline & & K & & $\mathrm{TH}$ & & $\begin{array}{l}\% \mathrm{G} \\
\mathrm{DP}\end{array}$ & BT & $\begin{array}{l}\% \mathrm{E} \\
\mathrm{XP}\end{array}$ \\
\hline FDI & 1 & 0.01 & - & .895 & - & .766 & - & .825 \\
\hline $\begin{array}{l}\% \text { GD } \\
\mathrm{P}\end{array}$ & & 4 & $\begin{array}{l}.829 * \\
*\end{array}$ & $* *$ & $\begin{array}{l}0.03 \\
9\end{array}$ & $* *$ & 0.43 & ** \\
\hline POLI & 0.01 & 1 & - & 0.13 & 0.14 & 0.63 & - & .880 \\
\hline TICA & 4 & & $.899 *$ & 8 & 3 & 5 & $\begin{array}{l}.907 \\
* * 7\end{array}$ & $* *$ \\
\hline
\end{tabular}

$\mathrm{L}$

RISK

$\begin{array}{llllllllll}\text { ECO } & 0 & 0 & 0 & 0 & 0 & 0 & 0 & 0 & 0000\end{array}$

NOM

IC

RISK

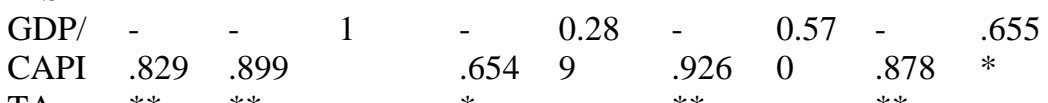

TA $* * \quad * * \quad * \quad * 2 * *$ * $\quad * *$

$\begin{array}{llllllllll}\text { GDP } & .895 & 0.13 & - & 1 & 0.32 & 0.50 & - & .818 & - \\ \text { GRO } & * * & 8 & .654 * & & 4 & 0 & 0.45 & * * & 0.55\end{array}$

$\begin{array}{lllll}\text { WTH } & 7 & 7 & 4\end{array}$

$\begin{array}{llllllllll}\text { INFL } & - & 0.14 & 0.289 & 0.32 & 1 & - & - & 0.17 & - \\ \text { ATI } & 0.03 & 3 & & 4 & & 0.33 & 0.08 & 7 & 0.15\end{array}$

$\begin{array}{llllll}\text { ON } & 9 & & 5 & 3 & 6\end{array}$

$\begin{array}{llllllllll}\text { CUR } & .766 & 0.63 & - & 0.50 & - & 1 & - & .779 & - \\ \text { RAC } & * * & 5 & 926 * & 0 & 0.33 & & 0.56 & * * & 0.57\end{array}$

$\begin{array}{lllllllll}\mathrm{RAC} & * * & 5 & .926 * & 0 & 0.33 & 0.56 & * * & 0.57 \\ \mathrm{C} & & & * & & 5 & 0 & & 6\end{array}$

$\mathrm{C}$
$\% \mathrm{GD}$

$\begin{array}{lllllllll}\text { PINA } & 0 & 0 & 0 & 0 & 0 & 0 & 0 & 0\end{array}$

NCI

AL

RISK

$\begin{array}{llllllllll}\text { FOR } & - & - & 0.570 & - & - & - & 1 & - & .908 \\ \text { EIG } & 0.43 & .907 & & 0.45 & 0.08 & 0.56 & & .713 & * * \\ \mathrm{~N} & 8 & * * & & 7 & 3 & 0 & & * & \end{array}$

$\begin{array}{lllllll}\mathrm{N} & 8 & * * & 7 & 3 & 0 & *\end{array}$

$\mathrm{T}$ 


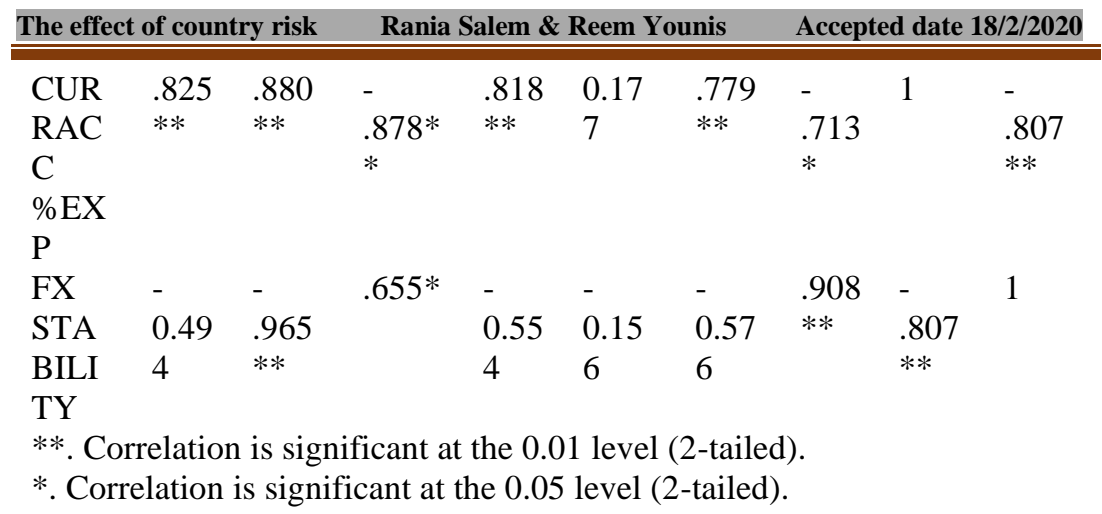

\subsection{DATA PROCESSING}

After testing for multicollinearity, economic, financial and political risks were computed from their measurements according to ICRG methodology as follows:

Economic risk $=$ GDP GROWTH + CURR ACC $\%$ GDP

Financial risk $=$ FOREIGN DEBT + FX STABILITY

Political risk $=$ Rating

Composite Country Risk $=0.5($ Economic Risk + Financial Risk + Political Risk)

The final correlation matrix between variables is presented below in table 3 .

Table 3 Correlations Matrix

$\begin{array}{lllll} & \text { FDI\%GDP } & \begin{array}{l}\text { Economic } \\ \text { Risk }\end{array} & \begin{array}{l}\text { Financial } \\ \text { Risk }\end{array} & \begin{array}{l}\text { Political } \\ \text { Risk }\end{array} \\ \text { FDI\%GDP } & 1 & .959^{* *} & -0.457 & -.846^{* *} \\ \text { Economic Risk } & .959 * * & 1 & -.611^{*} & -.797^{* *} \\ \text { Financial Risk } & -0.457 & -.611^{*} & 1 & 0.165 \\ \text { Political Risk } & -.846^{* *} & -.797^{* *} & 0.165 & 1\end{array}$

**. Correlation is significant at the 0.01 level (2-tailed).

*. Correlation is significant at the 0.05 level (2-tailed). 
The effect of country risk $\quad$ Rania Salem \& Reem Younis Accepted date 18/2/2020

Since economic risk is highly correlated with political risk (0.797), both variables could not be in one model or otherwise, the results would be inaccurate. Consequently, a total of 3 models are built as follows:

Model 1: Financial risk and political risk to test their effect on FDI in Egypt for the period 2005-2015

Model 2: Financial risk and economic risk to test their effect on FDI in Egypt for the period 2005-2015

Model 3: The composite risk to test its effect on FDI in Egypt for the period 2005-2015

In addition, it is important to identify which of the specific risks' measurements have significant effect on FDI flows. Therefore, another 3 models were built as follows:

Model 4: All filtered measurements of economic risk for the period 2005-2015 in Egypt

Model 5: All filtered measurements of financial risk for the period 2005-2015 in Egypt

Model 6: Political risk rating for the period 2005-2015 in Egypt

\section{RESULTS AND DISCUSSION 6.1 RESULTS}

Table 4 provides a summary of the results of the 6 multiple regression models. First, considering model (3) with the composite risk as the independent variable, the results show that the composite country risk is negatively and significantly associated with FDI flows to Egypt, as its p value is 0.002 which is less than 0.1 with an intercept value of -0.692 . This means that when the composite country risk increases, FDI is expected to decrease with 0.602 units, or in other words $60.2 \%$ in its flows. The whole model shows its significance as its $\mathrm{p}$ value is 0.002 which is less than 0.01 . Furthermore, the model's adjusted R2 is only $63.6 \%$, which is relatively low, indicating that only $63.6 \%$ from FDI flows is explained by composite country risk.

Country risk is then split into 2 different independent models; models 1 and 2. Model 1 tests the effect of financial and political 
risks on FDI flows to Egypt. Regression results show that financial risk does not have a relationship associated with FDI flows as the variable's significance is 0.64 which is more than $0.01,0.05$ and even 0.10 . On the other hand, political risk indicates a positive and significant relationship with FDI flows to Egypt as the variable's $p$ value is 0.001 with an intercept value of 0.231 . Which means that when political risk increases, FDI flows is expected to increase with 0.231 units, or in other words $23.1 \%$. However, this is illogical as investors are very skeptical about political risk because political risk is a risk beyond the host country's control. Therefore, countries may not be able to account for this risk. Hence, non-promising business investment atmosphere. The whole model showed its significance as its $p$ value is 0.000 which is less than 0.01 . Furthermore, the model's adjusted R2 is $77.5 \%$ which is higher than the adjusted R2 of model 3 , indicating that $77.5 \%$ of FDI flows is explained by the political risk variable.

Moving on to model 2 which tests the effect of economic and financial risks on FDI flows to Egypt. The regression results show that again, financial risk does not have a relationship associated with FDI flows as the variable's significance is 0.80 which is more than $0.01,0.05$ and 0.10 . On the other hand, the economic risk variable show that it has a positive and significant association with FDI flows to Egypt as the variable's $p$ value is 0.000 with an intercept value of 0.912 . This means that when economic risk indicators increase, FDI flows to Egypt is expected to increase its flows with 0.912 units, or in other words $91.2 \%$. The whole model showed its significance as its $\mathrm{p}$ value is 0.000 which is less than 0.01 . Moreover, the model's adjusted R2 is $93.4 \%$, which is the highest $\mathrm{p}$ value among all models, indicating that FDI flows to Egypt is $93.4 \%$ explained by economic risk indicators.

Furthermore, it is important to test each variable broken down to its measurements (models 4, 5, and 6). Starting with model 4 which tests the effect of economic risk indicators, GDP growth and current account as percentage of GDP, on FDI flows to Egypt. Regression results showed that both independent variables, GDP 
growth and current account, are positively and significantly associated with FDI flows, as their significance is 0.000 and 0.003 , respectively, which are less than 0.01 . GDP growth has an intercept value of 0.986 , this means that when GDP growth increases, FDI flows is also expected to increase by 0.986 units, or in other words $98.6 \%$. In addition, the current account has an intercept of 0.622 , meaning that when the current account increases in value, FDI flows is expected to increase with 0.622 units, or in other words $62.2 \%$. However, the current account results contradict with the expectations of the research, because Egypt has a negative sign in its current account which indicates a current account deficit. The overall model shows its significance as its $p$ value is 0.000 which is less than 0.01 . Furthermore, the model's adjusted R2 is $92 \%$ which is considered as the second highest $\mathrm{p}$ value among all models, indicating that $92 \%$ of FDI flowing to Egypt is explained by both, GDP growth and current account or economic risk indicators.

Moving on to model 5, which tests the effect of financial risk indicators, foreign debt and foreign exchange stability, on FDI flows to Egypt. Regression results showed that neither of the independent variables, foreign debt or foreign exchange stability were successful in determining the changes in FDI inflows as their significance were 0.936 and 0.476 , respectively, which are more than 0.01 and all alpha values. Furthermore, the whole model indicates an insignificant $p$ value of 0.326 . In addition, the model shows a very low adjusted R2 value of $5.5 \%$ which indicates that only $5.5 \%$ of FDI flows to Egypt is explained by foreign debt and foreign exchange stability. However, which are insignificant ( $\mathrm{p}$ value $>0.01$ ). Therefore, financial risk, as measured by these indicators, does not affect FDI inflows. Which also explains the insignificancy of financial risk as a whole in models 1 , and 2 . Progressing through the last regression model, model 6, which tests the effect of political risk ratings on FDI flows to Egypt. Regression results show that political risk rating is positively and significantly associated with FDI inflows as its significance is 0.001 which is less than 0.01 . Political risk has an 
intercept value of 0.246 which means that when political risk increases, FDI inflows is expected to increase by 0.246 units, or in other words $24.6 \%$. However, again, this is illogical. Moreover, the model as a whole showed significance of 0.001 which is less than 0.01 . Also, the model's adjusted R2 value is $68.5 \%$, which is an accepted value but other models showed higher adjusted R2 results.

The general adjusted R2 results ranged from 5.5\% (model 5) to 93.4\% (model 2). As suggested by Rogmans \& Ebbers (2013), the wide range of values and the relatively low $\mathrm{R} 2$ is directly associated with the choice of FDI as percentage of GDP as the dependent variable. The aim of the regression models is to explain the behavior of FDI not the size of the economy, purchasing power or the population's income which can measured by the GDP. We believe that if FDI inflows data was available, and can be used as the dependent variable, the research would have got better, and more accurate results. This is reflected in the research limitation is chapter 5 .

As mentioned in the methodology section, multicollinearity issues have been eliminated. Multicollinearity diagnostics tests were conducted, for each regression model, in order to make sure that the VIF (Variance Inflation Factor) is below 5 or 10. Because usually, researchers have concerns about multicollinearity when VIF values are above 5 or 10 .

Accordingly, after interpreting the results excluded from the models, the hypotheses generated in the literature review can be tested for validity. Firstly, economic risk has a positive influence on FDI inflows to Egypt. Therefore, the researcher has to reject the hypothesis, ; economic risk has a negative effect on foreign direct investment inflows to Egypt. As a result, there are no enough significant evidence to reject nor accept the null hypothesis; economic risk has no effect on foreign direct investment inflows to Egypt, because the results infer that there is a positive relationship not negative nor none. Secondly, financial risk was found to have no significant influence on FDI inflows to Egypt. Therefore, the researcher has to reject the 
hypothesis; financial risk has a negative effect on foreign direct investment inflows to Egypt. As a result, there are no enough significant evidence to reject the null hypothesis; financial risk has no effect on foreign direct investment inflows to Egypt. Lastly, political risk was found to have a positive association with FDI inflows to Egypt. Therefore, the researcher has to reject the hypothesis; political risk has a negative effect on foreign direct investment inflows to Egypt. As a result, there are no enough significant evidence to reject nor accept the null hypothesis; political risk has no effect on foreign direct investment inflows to Egypt, because the results infer that there is a positive association not negative nor none.

Table 4 Multiple Regression Models' Results

\begin{tabular}{|c|c|c|c|c|c|c|}
\hline & Model & Model & Model & Model & Model & Model 6 \\
\hline & 1 & 2 & 3 & 4 & 5 & \\
\hline Constant & $\begin{array}{l}11.291 \\
(0.001) \\
* *\end{array}$ & $\begin{array}{l}0.025 \\
(0.987)\end{array}$ & $\begin{array}{l}12.333 \\
(0.000) \\
* *\end{array}$ & $\begin{array}{l}2.297 \\
(0.003) \\
* *\end{array}$ & $\begin{array}{l}17.797 \\
(0.221)\end{array}$ & $\begin{array}{l}7.090 \\
(0.000) \\
* *\end{array}$ \\
\hline $\begin{array}{l}\text { ECONOMIC } \\
\text { RISK }\end{array}$ & 0 & $\begin{array}{l}0.912 \\
(0.000) \\
* *\end{array}$ & 0 & 0 & 0 & 0 \\
\hline GDP Growth & 0 & 0 & 0 & $\begin{array}{l}0.986 \\
(0.000) \\
* *\end{array}$ & 0 & 0 \\
\hline $\begin{array}{l}\text { Current } \\
\text { Account } \% \text { of } \\
\text { GDP }\end{array}$ & 0 & 0 & 0 & $\begin{array}{l}0.622 \\
(0.003) \\
* *\end{array}$ & 0 & 0 \\
\hline $\begin{array}{l}\text { FINANCIAL } \\
\text { RISK }\end{array}$ & $\begin{array}{l}-0.317 \\
(0.64)\end{array}$ & $\begin{array}{l}0.200 \\
(0.80)\end{array}$ & 0 & 0 & 0 & 0 \\
\hline Foreign Debt & 0 & 0 & 0 & 0 & $\begin{array}{l}0.075 \\
(0.936)\end{array}$ & 0 \\
\hline FX Stability & 0 & 0 & 0 & 0 & $\begin{array}{l}-2.370 \\
(0.476)\end{array}$ & 0 \\
\hline $\begin{array}{l}\text { POLITICAL } \\
\text { RISK }\end{array}$ & $\begin{array}{l}0.231 \\
(0.001) \\
* *\end{array}$ & 0 & 0 & 0 & 0 & $\begin{array}{l}0.246 \\
(0.001) \\
* *\end{array}$ \\
\hline $\begin{array}{l}\text { Composite } \\
\text { Risk }\end{array}$ & 0 & 0 & $\begin{array}{l}-0.602 \\
(0.002) \\
* *\end{array}$ & 0 & 0 & 0 \\
\hline
\end{tabular}




\begin{tabular}{lllllll}
\multicolumn{1}{l}{ The effect of country risk } & \multicolumn{3}{c}{ Rania Salem \& Reem Younis } & \multicolumn{2}{c}{ Accepted date 18/2/2020 } \\
\hline \hline Adjusted R2 & $77.5 \%$ & $93.4 \%$ & $63.6 \%$ & $92 \%$ & $5.5 \%$ & $68.5 \%$ \\
SSE & 18.601 & 5.473 & 33.807 & 6.599 & 78.072 & 29.302 \\
Std. Error of & 1.5148 & 0.827 & 1.9381 & 0.9082 & 3.1239 & 1.80436 \\
Estimates & & & & & & \\
Model & 0.001 & 0.000 & 0.002 & 0.000 & 0.326 & 0.001 \\
Significance & $* *$ & $* *$ & $* *$ & $* *$ & & $* *$ \\
Note: Significant at *5 and **1 percent levels & & &
\end{tabular}

\subsection{DISCUSSION}

The 6 models yielded multiple understandings about the variables explaining the FDI behavior in Egypt. As shown in the results above, economic risk indicators including, both, GDP growth and current account have positive significant impact on the behavior of FDI inflows to Egypt. This result is consistent with Onyeiwu's (2004), Kok and Ersoy's (2009) and Hunjra's (2013) findings. Onyeiwu (2004) studied the economic growth indicators, such as GDP growth, he found that GDP growth is one of the important factors that attract FDI to a country because GDP growth is an indicator of economic stability not risk. On the other hand, this result contradicts with Paudel's (2016) findings, which states that GDP growth, among other factors, affect FDI inflows negatively. In contrast, current account results show a positive relationship with FDI inflows to Egypt. Nevertheless, Egypt has been having a negative sign in its current account; current account deficit since the year 2008 and the deficit has been increasing since then. Thus, when current account deficit increase, FDI inflows decrease subsequently and vice versa. The results conform with Sahoo, Babu \& Dash (2014). The results can be an indication of the temporary economic cycles. Meaning that Egypt might have been taking inflows of goods and services in order to finance its economic activities and utilizing these resources in order to grow internally.

In conclusion, the model with economic risk variables show mixed results between FDI inflows and economic risk. Results indicate that there is a positive relationship between the current account deficit that Egypt has and FDI inflows. In addition, 
results show that GDP growth affects economic risk positively; hence lower economic risk; more stability and consequently, higher FDI inflows.

Moving on to financial risk indicators, foreign debt and foreign exchange stability, neither of the two factors indicates their significance in explaining the behavioral changes in FDI flows to Egypt, as mentioned in the results section above. This result is consistent with Hunjra's (2013) view, which stated that foreign exchange rates does not have an impact on FDI flows. However, the rest of the result (foreign debt) contradicts with kok and Ersoy's (2009) view, which stated that total foreign debt as a percentage of GDP has a negative effect on FDI flows.

Progressing through the last component of country risk, political risk. Political risk scores have been collected from Bloomberg Country Risk Political Scores for Egypt as mentioned before. Bloomberg Country Risk Political Scores measures political risk of a country relative to other developed countries. The higher the scores, the more the stability of the country and the less the risk. Scores range from 0 to 100. Egypt's scores ranged from 12.54 to 25.07 which indicates relatively low scores; high political risk. Results show that the given political risk scores positively and significantly affect FDI flows. However, this result is inconsistent with Rauf et al's (2016) findings where the study stated that political stability affects FDI positively. However, in this study, political scores are low, so political scores coefficients in model 1 and 6 should have been with a negative sign. This inaccuracy might have arisen from having the first 4 years of the data missing because of the availability of data, this is reflected in the research limitations section in chapter 5. On the other hand, Al-Khouri (2015) suggested that lower levels of political risk are associated with the positive coefficient because better investments come with higher political scores. In addition, the positive relationship between political risk and FDI can also be arising from investors that invest in unstable countries with potential growth in order to get a high required rate of return. Accordingly, when the country 
reaches economic growth, investors would have well established grounds for further growth.

Lastly, the composite country risk (model 3), or as referred to by Rogmans \& Ebbers (2013), environmental risk. Composite risk affects FDI flows negatively and significantly as mentioned in the results section. This result is consistent with Rogmans \& Ebbers's (2013) findings where they stated that environmental or overall country risk is negatively and significantly associated with FDI performance for the 1998-2008 period in the MENA region. This is reflected in the results as the coefficient of composite risk is 0.602. However, the whole model did not show high adjusted R2 which means that investors are not as concerned about the overall risk of a country. Because, usually, when investors decide to invest in the MENA region, all locations are equally the same for them and in most cases, investors hedge their risk before entering a slightly risky market (Rogmans \& Ebbers, 2013). Moreover, it is also suggested that investors are more concerned about risk factors broken down rather than the composite or environmental risk.

\section{CONCLUSION \\ 7.1 RESEARCH FINDINGS}

Egypt has always been a country of high potentials. In this research, the overall country risk and its components individually namely, economic, financial and political risks, and their effect on foreign direct investment in Egypt have been studied. Firstly, looking into the overall country risk, it was found that the composite country risk has a negative significant relationship with FDI flows as expected after discussing the literature. However, the composite risk did not show its value in the models as it showed a relatively low percentage of adjusted R2. This means that investors are not highly concerned about the overall composite risk, they are more concerned about the components of country risk. Secondly, looking into the components of country risk, first, economic risk components. The role of GDP growth 
and current account have highly significant and positive influence on FDI flows. The best model has economic risk components which reflects that investors are highly and mostly concerned about economic risk, rather than any other country risk component. Second, financial risk. Results show that it is neither significant nor has an effective influence on FDI flows to Egypt. However, other researchers identified some components to have an impact -either positive or negative-. Therefore, this finding contradicts with some literatures and conforms with others. Lastly, political risk. In difference with most of the existing researches, political risk is found to have no significance and even positive coefficient, meaning that high political risk is associated with high FDI flows. This may be because investors are not sceptic when it comes to the MENA region because, as mentioned before, when investors decide to invest in the MENA region, all countries are equally the same for them, in terms of potential risk. Also, investors usually hedge against any expected potential risks. In conclusion, economic risk components have the most significant impact on FDI flows to Egypt.

\subsection{RESEARCH LIMITATIONS AND FUTURE RESEARCH}

This research is based on FDI as percentage of GDP as the dependent variable of the equation. This is the main limitation of this research, as this was reflected on the results, correlation matrix and the multicollinearity tests conducted. This research aims to provide an understanding about FDI behavior only, not an understanding about FDI along with the size of the economy, purchasing power, or population's income that are measured by the GDP. However, due to the availability of data, data related to FDI inflows only could not be collected. Moreover, the multicollinearity problem restricted us to only use specific measurements of each variable, which resulted in excluding potential value-added variables from the models. Also, two other problems were raised due to the availability of data, resources and 
information. Firstly, the political risk data started from 2009. However, this research is supposed to cover the period starting the year 2005 till the year 2015 which means that the research has four missing years in political risk data. This is surely reflected on the results of political risk which contradicted with most of the literature. Secondly, data for the year 2016 could not be collected, also due to the availability of data. It was better to extend the research to the year 2016 because of the many highlights that happened during that year. One of the main economic highlights is the Egyptian Pound floatation on November 3rd with 48 percent devaluation in currency. Along with a hike of 30 to 46.8 percent in fuel prices on the same day. Major events like this should have been reflected in the research but data was neither available nor accessible. The last limitation is that Egypt has been receiving so little attention in the academic context which was clearly reflected in chapter two; literature review, where references were mainly from literatures on MENA region and the world as a whole but none specifically related to Egypt.

Future research may include cross-sectional analysis, analyzing reginal countries such as the United Arab Emirates, and other MENA region countries. It would also be interesting to include more indicators of risk, especially economic and political risks, rather than the composite risk. Moreover, future research may include more risk variables and measures. 


\section{REFERENCES}

(2017). Retrieved from World Bank: http://data.worldbank.org/indicator/BX.KLT.DINV.WD.GD.ZS?end= $2015 \&$ start $=2005$

(2017). Retrieved from Trading Economies: http://www.tradingeconomics.com/egypt/rating

Aliber, R. A. (1970). A theory of foreign direct investments. C. Kindleberger.

Al-Khouri, R. (2015). Deteminants of foreign direct and indirect investment in the MENA region. The Multinational Business, 23(2), 148-166.

Belloumi, M. (2014). The relationship between trade, FDI and economic growth in Tunisia: An application of the autoregressive distributed lag model. Economic Systems.

Buckley, P. (2007). The determinants of Chinese outward foreign direct investment. Jounral of International Business Studies, 38, 499-518.

Busse, M., \& Hefeker, C. (2005). Political risk, institutions and foreign direct investment. Hamburg Institute of International Economics.

Butler, K., \& Joaquin, D. (1998). A note on political risk and the required rate of return on foreign direct investment. Journal of International Business Studies, 29(3), 599-606.

CBE. (2017). External Position of the Egyptian Economy. Retrieved from Central Bank of Egypt.

Chakrabarti, A. (2001). The Determinants of Foreign Direct Investment: Sensitivity Analyses of Cross-Country Regressions. Kyklos, 54, 89-114.

Choi, J. J., \& Tsai, E. C. (2015). Strategic and Financial Deteminants of Foreign Direct Investments. Value Creation in Multinational Enterprise, 19-60.

Churchill, G. (1979). A paradigm for developing better measures for marketing contrasts. Journal of Marketing Research, 64-73.

Click, R. W. (2005). Financial and Political Risks in US Direct Foreign Investment. Journal of International Business Studies, 559-575.

Cosset, J., \& Roy, J. (1991). The determinants of country risk ratings. Journal of International Business Studies, 22(1), 135-142.

DailyMail, A. P. (2016, November 3). Retrieved from http://www.dailymail.co.uk/wires/ap/article-3900352/Egypt-devaluescurrency-meeting-key-IMF-demand.html 
Dutta, N., \& Roy, S. (2011). Foreign Direct Investment, Financial Development and Political Risks. The Journal of Developing Areas, 44(2), 303-327.

Elshamy, H. M. (2015). The economic determinants of Chinese foreign direct investment in Egypt. Journal of Chinese Economic and Foreign Trade Studies, 20-26.

Froot, K., \& Stein, J. (1991). Exchange rates and foreign direct investment. Journal of Economics, 1191-1217.

Gorg, H., \& Greenaway, D. (2004). Much ado about nothing? Do domenstic firms really benefit from foreign direct investment? World Bank Research Observer, 171-197.

Grosse, R., \& Treviño, L. (2005). New institutional economics and FDI location in central and eastern Europe. Management International Review, 45(2), 123-146.

Haider, G. G. (2014). Does politicak risk deter FDI inflow?: An analytical approach using panel data and factor analysis. Journal of Economic Studies, 41(2), 233-252.

Hanjra, A., Raza, S., \& Asif, M. (2013). Impact of Macroeconomic Variables on Foreign Direct Investment in Pakistan. Bulletin of Business and Economics, 2(2), 40-52.

Harms, P., \& Ursprung, H. (2002). Do civil an polotical repression really boost foreign direct investments? Economic Enquiry, 40(4), 651663.

Herring, E. J. (1983). Introduction and overview in Managing International Risk. Cambridge University Press, 1-22.

Hogan, K. M., Lipton, A. F., \& Olson, G. T. (2015). An evaluation of Country Risk in Assessing Direct Foreign Investment. In Application of Management Science, 251-276.

Iqbal, Z. (n.d.). Economic Challenges in the Middle East and North Africa: An Overview, Macroeconomic Issues and Policies in the Middle East and North Africa, International Monetary Fund. Washington, DC.

Kamaly, A. (2002). Evaluation of FDI flows into the MENA region. Working paper series, Economic Research Forum, Cairo.

Kok, R., \& Ersoy, B. A. (2009). Analysis of FDI in Developing Countries. International Journal of Economics, 105-123.

Kumar, R. (2011). Research Methodology: A Step-by-Step Guide for Beginners (3 ed.). Sage Publications. 
Law, S. H. (2010). FDI and economic growth: New evidence on the role of financial markets. Economics Letters.

Lipsey, R. (2001). Foreign direct investment in three financial crises. NBER Working Oaoer.

Liu, T., Hammoudeh, S., \& Thompson, M. A. (2013). A momentum threshold model of stock prices and country risk ratings: Evidence from BRICS countries. Journal of International Financial Markets, Institutions \& Money, 99-112.

Mall, S. (2013). Foreign Direct Investment in Pakistan: A Time Series Analysis with Autoregressive Distribution Lag (ARDL) Approach. International Jounral of Computer Applications, 7-16.

Massoud, M., \& Raiborn, C. (2003). Managing risk in global operations. The journal of Corporate Accounting an Finance, 14(6), 4149.

Meldrum, D. H. (2000, January). Country Risk and Foreign Firect Investment: CUSTOMIZED, SYSTEMATIC COUNTRY RISK ASSESSMENT IS CRITICAL FOR COMPANIES THAT COMTEMPLATE ACTIVITY ABROAD. Palgrave Macmillan Journals, 35(1), 33-40.

Meyer, K., \& Sinani, E. (2009). When and where does foreign direct investment generate positive spillovers? A meta-Analysis. Journal of International Business Studies, 40, 1075-1094.

Naguib, R. I., \& Xu, F. (2016). Economic Growth, Foreign Direct Investment and Privatisation in Egypt and China: Preliminary Results. Global Business \& Economics Anthology, 138-159.

Nordal, K. B. (2001). Country risk, country risk indices and valuation of FDI: a real options approach. Foundation for Research in Economics and Business Administration, 197-217.

ODI. (1997). FDI Flows to Low-Income Countries: A Review of the Evidence. London: Overseas Development Institute.

Onyeiwu, S. (2004). Analysis of FDI flows to feveloping countries: is the MENA region different? Retrieved from www.mafhoum.com/press6/172E11.pdf

Onyeiwu, S. (2008). Does Investment in Knowledge and Technology Spur Optimal FDI in the MENA Region: Evidence from Logit and Cross-Country Regression. African Economic Development Conference. Tunis.

Paudel, R. (2016). Role of Human Development and Governance in Foreign Direct Investment in the Post Reform Era: The Case of 
Tanzania. International Journal of Research \& Methodology in Social Science, 5-18.

Ramcharran, H. (1999). Trade liberalization in servicesL an analysis of the obstales and the opportunities for trade expansionn by USA Law Firms. Multinational Business Review, 7(1), 27-36.

Rauf, S., Mehmood, R., \& Mehmood, S. (2016). Intergrated model to measure the impact of terrorism and political stability on FDI inflows: empirical study of Pakistan. International Journal of Economics and Finance, 1-7.

Rehman, H. U. (2016, Winter). Comparative Analysis of The SocioEconomic Determinants of Foreign Direct Investment: Evidence from Pakistan. Pakistan Economic and Social Review, 54(2), 255-274.

Rogmans, T., \& Ebbers, H. (2013). The determinants of foreign direct investment in the Middle East North Africa region. International Journal of Emerging Markets, 240-257.

Sahoo, M., Babu, M., \& Dash, U. (2014). Effects of FDI flows on Curreny Account Balances: Do Globalisation and Institutional Quality Matter? Indian Institute of Technology Madras, 1-21.

Sahoo, M., Babu, M., \& Dash, U. (2014). Effects of FDI on Current Account Balances: Do Globalisation and Institutional Quality Matter? Indian Institute of Technology Madras, 1-21.

Saunders, M., Lewis, P., \& Thornhill, A. (2012). Research Methods for Business Students (6 ed.). Pearson.

Steiner, C. (2010). An overestimated relationship? Violent political unrest and tourism foreign direct investment in the Middle East. International Journal of Tourism Research, 12(6), 726-738.

Tung, S., \& Cho, S. (2001). Determinants of regional investment decisions in China: an econometric model of tax incentice policy. Review od Quantitative Finance and Accounting, 17(2), 167-185.

Vijayakumar, J., Rasheed, A. A., \& Tondkar, R. (2009). Foreign Direct Investment and Evaluation of Country Risk: An Empirical Investigation. Multinational Buiness Review, 17(3), 181-204.

Wyk, J., \& Lal, A. (2010). FDI location drivers and risks in MENA. Journal of International Business Research, 9(2), 99-116.

Zghidi, N., Sghaier, I. M., \& Abida, Z. (2016). Does Economic Freedom Enhance the Impact of Foreign Direct Investment on Economic Growth in North African Countries? A Panel data Analysis. Afican development Review, 64-74, No. 1, pp. 46-66 